\title{
Selenium in serum and neoplastic tissue in breast cancer: correlation with CEA
}

\section{K Charalabopoulos*, , A Kotsalos', A Batistatou'², A Charalabopoulos ${ }^{3}$, P Vezyraki', D Peschos², V Kalfakakou' and A Evangelou'}

'Department of Physiology, Clinical Unit, Medical Faculty, University of loannina, I 3, Solomou str., 452 2I loannina, Greece; ${ }^{2}$ Department of Pathology, Medical Faculty, University of loannina, loannina, Greece; ${ }^{3}$ Department of Surgery, Peterborough and Stamford Hospitals, Cambridgeshire, UK

Trace element selenium (Se) is regarded to be a breast cancer preventive factor involved in multiple protective pathways. In all, 80 women with breast cancer who underwent a radical mastectomy were enrolled in the study. Serum Se and carcinoembryonic antigen levels were measured using a fluorometric and IRMA assay, respectively. Se tissue concentration was determined by a tissue extracting fluorometric assay. For statistical analysis purposes t-test was used and $P$-values $<0.001$ were regarded as statistically significant. Serum Se was $42.5 \pm 7.5 \mu \mathrm{g} I^{-1}$ in breast cancer patients and $67.6 \pm 5.36 \mu \mathrm{g} \mathrm{I}^{-1}$ in the age-matched control group of healthy individuals. Serum carcinoembryonic antigen in patients was $10 \pm 1.7 \mathrm{Uml}^{-1}$ (normal $<2.5 \cup \mathrm{ml}^{-1}$ in nonsmokers/ $<3.5 \mathrm{U} \mathrm{ml}^{-1}$ in smokers). A statistically significant difference was found for both serum Se and CEA between two groups studied $(P<0.00 \mathrm{I})$. Neoplastic tissue Se concentration was $2660 \pm 210 \mathrm{mg} \mathrm{g}^{-1}$ tissue; its concentration in the adjacent non-neoplastic tissue was $680 \pm 110 \mathrm{mgg}^{-1}$ tissue $(P<0.001)$. An inverse relationship between Se and CEA serum levels was found in the two groups studied $(r=-0.794)$. There was no correlation between serum/tissue Se concentration and stage of the disease. The decrease in serum Se concentration as well as its increased concentration in the neoplastic breast tissue is of great significance. These alterations may reflect part of the defence mechanisms against the carcinogenetic process.

British Journal of Cancer (2006) 95, 674-676. doi:I0.1038/sj.bjc.6603292 www.bjcancer.com

Published online I August 2006

(c) 2006 Cancer Research UK

Keywords: selenium; breast cancer; carcinoembryonic antigen (CEA)

Breast cancer is regarded as the third most common malignancy in humans and the second, after skin cancer, in women (Greenlee et al, 2000). Approximately, 150000 women in the United States of America are affected every year (Wolff and Weston, 1997). Much knowledge has been accumulated on the aetiology and pathogenesis of this malignancy implicating genetic, hormonal and environmental factors (Simopoulos, 2004). The influence of micronutrient status on breast cancer development in humans is, nowadays, under continuous investigation. It has been postulated that a high intake of micronutrients in diet may prevent carcinogenesis (Lianidou et al, 1997; Charalabopoulos et al, 2003). Trace elements play an important role in a number of biological processes by activating or inhibiting various enzymes (Garg et al, 1994). Selenium (Se) is an essential nonmetallic trace element and its plasma and tissue concentration is regulated by incompletely understood homeostatic mechanisms. Se exists in the body in the form of selenocystein, a component of selenoproteins and has important structural and enzymic roles, such as antioxidant activity (Huang et al, 1999, Rayman, 2000; Rayman, 2005). Cellular oxidative damage is a general mechanism for cell and tissue injury. Oxidative stress in the target tissue has been

*Correspondence: Professor KA Charalabopoulos;

E-mail: kcharala@cc.uoi.gr

Revised I 2 June 2006; accepted 3 July 2006; published online I August 2006 suggested to play an important role in carcinogenic process. Thus, Se may act as an antitumoural agent although more studies are needed to investigate the actual role of antioxidants and their possible relationships with trace elements alterations in the pathogenesis of breast cancer (Bock et al, 1991; Gerber et al, 1996). Furthermore, it has been shown that Se supplementation decreases the COX-2 protein and PGE-2 levels in colorectal cancer cells. In addition, Se exhibits an antiproliferative effect modulating cellular proliferation in G1 phase in both normal and neoplastic cells impairing the expression of c-fos and c-myc oncogenes (Kuo et al, 2002). However, other prospective studies have failed to confirm these findings (Garland et al, 1995; Ghadirian et al, 2000). A strong relationship between low-serum Se concentration and increased risk of breast cancer has been documented (Bratakos et al, 1990a, b; Mannisto et al, 2000; Kuo et al, 2002; Lopez-Saez et al, 2003).

The aim of the present study was to determine the levels serum Se in breast cancer patients and healthy controls and to correlate them with Se levels in neoplastic tissue.

\section{MATERIALS AND METHODS}

In all, 80 women with infiltrative ductal carcinoma (nonspecific type, stages I-IV) who underwent radical mastectomy, $45 \pm 10.6$ years old, pre- and postmenopausal, were enrolled in the study. 
Table I Se concentration in serum $\left(\mu \mathrm{g}^{-1}\right)$ and breast tissue $\left(\mu \mathrm{gg}^{-1}\right.$ tissue)

\begin{tabular}{|c|c|c|c|c|}
\hline & $\begin{array}{c}\text { A } \\
\text { Serum } \\
\left(\mu \mathrm{I}^{-1}\right)(x \pm \text { s.d. })\end{array}$ & $\begin{array}{c}\text { B } \\
\text { Neoplastic tissue } \\
\left(\mu \mathrm{g} \mathrm{g}^{-1} \text { tissue }\right)\end{array}$ & $\begin{array}{c}\text { C } \\
\text { Non-neoplastic tissue } \\
\left(\mu \mathrm{gg}^{-1} \text { tissue }\right)(x \pm \text { s.d. })\end{array}$ & $\begin{array}{l}t \text {-test } * P \text {-value } \\
P<0.001\end{array}$ \\
\hline \multicolumn{5}{|l|}{ | } \\
\hline $\begin{array}{l}\text { Breast cancer patients } \\
\text { ॥ }\end{array}$ & $42.5 \pm 7.5$ & $2660 \pm 210$ & $680 \pm 110$ & SS between IA and IIA \\
\hline Healthy individuals & $67.6 \pm 5.36$ & NA & NA & SS between IB and IC \\
\hline
\end{tabular}

Abbreviations: $x \pm$ s.d., mean value \pm s.d.; NA, nonapplicable; $S S$, statistically significant; ${ }^{2}$-value $<0.00$ I is considered as statistically significant.

A female aged matched population group (consisting of 250 individuals) was selected for comparison of the laboratory data (Kallistratos et al, 1985; Charalabopoulos et al, 2006). In patients, serum Se levels were measured, at the time of diagnosis before any kind of treatment was started, by the fluorometric method (Watkinson's) modified by Thorling. This is a specific and very sensitive method among others (eg phasmatometric, nonflame molecular absorption, netronic activation, volumetric method) detecting Se at a quantity of $0.002 \mu \mathrm{g}$ and is considered the method of choice throughout Europe (Thorling et al, 1986). Whole blood $(10 \mu \mathrm{l})$ was taken and centrifuged. The samples were preserved at $-4^{\circ} \mathrm{C}$. Neoplastic and healthy tissue samples surrounding the tumour were taken during operation and preserved in liquid $\mathrm{N}_{2}$. To determine Se tissue concentration, a modified extracting fluorometric assay, similar to the above described, was used. Serum CEA levels were measured by IRMA assay, using commercial kits. For statistical analysis purposes, $t$-test was used and $P$-values $<0.001$ were regarded as statistically significant. Table 1 shows laboratory and statistical data of the groups studied.

\section{RESULTS}

Serum Se was $42.5 \pm 7.5 \mu \mathrm{gl}^{-1}$ in breast cancer patients and $67.6 \pm 5.36 \mu \mathrm{gl}^{-1}$ in the age-matched control group of healthy individuals. Neoplastic tissue Se concentration was $2660 \pm 210 \mathrm{mg} \mathrm{g}^{-1}$ tissue; its concentration in the adjacent nonneoplastic tissue was $680 \pm 110 \mathrm{mg} \mathrm{g}^{-1}$ tissue. Compared to control group Se concentration in serum was lower in breast cancer patients $(P<0.001)$. A statistical significant difference was also found between Se concentration in neoplastic breast tissue compared to normal tissue samples surrounding the neoplastic area; Se levels were almost four-fold higher in neoplastic tissue. Serum CEA levels in breast cancer patients were $10 \pm 1.7 \mathrm{U} \mathrm{ml}^{-1}$ (normal $<2.5 \mathrm{U} \mathrm{ml}^{-1}$ in nonsmokers/ $<3.5 \mathrm{U} \mathrm{ml}^{-1}$ in smokers, the mean concentration in the control group was $2.3 \mathrm{U} \mathrm{ml}^{-1}$ ). An inverse relationship between Se and CEA serum levels was found in the two groups studied $(r=-0.794)$. No correlation between serum/tissue Se concentration and stage of the disease was found.

\section{DISCUSSION}

Breast cancer is an important contributor to morbidity and mortality in humans. Trace element Se has been regarded as a breast cancer preventive factor (Kallistratos et al, 1989; Medina et al, 2001). However, in a large study a nonsignificant relationship between Se supplementation and increased breast cancer risk was shown (Clark et al, 1996). Se absorption is a complex, poorly understood process. Studies in rats have provided us with some information but little is known about this mechanism in humans. There is a particular Se-containing gene that encodes for Secontaining proteins and its various polymorphisms may lead to decreased element absorption (Esworthy et al, 1995). The basal amount of dietary Se is also debated. Dietary intakes show a large geographic variation mainly due to differences in Se bioavailability. In Greece the Se concentration in 315 examined foods was shown to be lower than other European countries and closer to UK. The daily Se intake of Greeks is estimated to approximately $110 \mu \mathrm{g}$ (Kallistratos et al, 1985; Bratakos et al, 1987; Bratakos et al, 1990b; Charalabopoulos et al, 2006).

Human body Se is incorporated into the polypeptide backbone of some proteins and through them it regulates the cellular antioxidant defense system, DNA damage and protein function. Se also controls cell-mediated immunity and B-cell function. The lower serum Se levels in cancer patients can be attributed to either lower Se intake, to sequestration of this element by the tumour cells or both (Di Ilio et al, 1985; Bratakos et al, 1990a).

To our best knowledge, the present study is the fourth one in the last 40 years (Pub-Med search) providing information regarding the neoplastic tissue Se concentration in breast cancer patients and the first one providing data for serum/tissue Se concentrations simultaneously, in association with serum CEA levels (Garg et al, 1994; Sharma et al, 1994; Kuo et al, 2002). It is notable that Se concentration in the neoplastic tissue was nearly fourfold greater than in the adjacent normal breast tissue. Our findings regarding serum/tissue Se levels in patients suffering from breast cancer are in agreement with other reports in patients with lung, gastric, renal, colorectal and breast cancer, where an increased concentration of Se in the neoplastic tissue was found (Garg et al, 1994; Sharma et al, 1994; Burguera et al, 1995; Kuo et al, 2002; Charalabopoulos et al, 2006).

It is not clear whether the increased Se concentration in the cancerous tissue is responsible for the decreased serum Se levels found in these patients or if the decreased serum Se levels precede the development of breast cancer. Another consideration is the significance of the increased Se concentration in neoplastic tissue. An attractive hypothesis is that it is part of the defence mechanisms against the neoplastic process. This concept is greatly supported by the already above-mentioned antioxidant action of Se. The usefulness and the significance of our findings should be clarified with further future investigation.

\section{REFERENCES}

Bock A, Forchhammer K, Heider J, Baron C (1991) Selenoprotein synthesis: an expansion of the genetic code. Trends Biochem Sci 16: $463-467$
Bratakos MS, Kanaki HC, Waite-Vasiliou A, Ioannou PV (1990b) The nutritional selenium status on healthy Greeks. Sci Total Environ 91: $161-176$ 
Bratakos MS, Vouterakos TP, Ioannou PV (1990a) Selenium status of cancer patients in Greece. Sci Total Environ 92: 207-222

Bratakos MS, Zafiropoulos TF, Siscos P, Ioannou PV (1987) Selenium in foods produced and consumed in Greece. J Food Sci 52: 817-822

Burguera JL, Villasmil LM, Burguera M, Carrero P, Rondon C, de Abel de la Cruz AM, Brunetto MR, Gallignani M (1995) Gastric tissue selenium levels in healthy persons, cancer and non-cancer patients with different kinds of mucosal damage. J Trace Element Med Biol 9: 160-164

Charalabopoulos K, Karkabounas S, Charalabopoulos AK, Papalimneou V, Ioachim E, Giannakopoulos X (2003) Inhibition of benzo (a) pyreneinduced carcinogenesis by vitamin $\mathrm{C}$ alone and by vitamin $\mathrm{C} /$ viatamin $\mathrm{E}$ and selenium/glutathione. Biol Trace Elements Res 93: $201-211$

Charalabopoulos K, Kotsalos A, Karkabounas S, Vezyraki P, Kalfakakou V, Metsios A, Golias C, Charalabopoulos A, Batistatou A, Evangelou A (2006) Low selenium levels in serum and increased concentration in neoplastic tissues in patients with colorectal cancer. Correlation with serum carcinoembryonic antigen. Scand J Gastroenterol 41: 359-360

Clark LC, Combs Jr GF, Turnbull BW, Slate EH, Chalker DK, Chow J, Davis LS, Glover RA, Graham GF, Gross EG, Krongrad A, Lesher Jr JL, Park HK, Sanders Jr BB, Smith CL, Taylor JR (1996) Effects of selenium supplementation for cancer prevention in patients with carcinoma of the skin. A randomised control trial. Nutritional prevention of Cancer Study Group. JAMA 276: $1957-1963$

Di Ilio C, Sacchetta P, Del Boccio G, La Rovere G, Federici G (1985) Glutathione peroxidase glutathione $S$-transferase and glutathione reductase activities in normal and neoplastic human breast tissue. Cancer Lett 29: $37-42$

Esworthy RS, Baker MA, Chu FF (1995) Expression of selenium dependent glutathione peroxidase in human breast tumor cell lines. Cancer Res 55: $957-962$

Garg AN, Singh V, Weiginwar RG, Agdeo VN (1994) An elemental correlation study in neoplastic and normal breast tissue with successive clinical stages by neutron activation analysis. Biol Trace Element Res 46: $185-202$

Garland M, Morris JS, Stampfer MJ, Colditz GA, Spate VL, Baskett CK, Rosner B, Speizer FE, Willett WC, Hunter DJ (1995) Prospective study of toenail selenium levels and cancer among women. J Natl Cancer Inst 87: $497-505$

Gerber M, Astre C, Segala C, Saintot M, Scali J, Simony-Lafontaine J, Grenier J, Pujol H (1996) Oxidant - antioxidant status alterations in cancer patients: relationship to tumor progression. J Nutr 126(Suppl 4): $1201-1207$
Ghadirian P, Maisonneuve P, Perret C, Kennedy G, Boyle P, Krewski D, Lacroix A (2000) A case-control study of toenail selenium and cancer of breast, colon, and prostate. Cancer Detect Prev 24: 305-313

Greenlee RT, Murray T, Bolden S, Wingo PA (2000) Cancer statistics. CA Cancer J Clin 50: 7-33

Huang YL, Sheu JIG, Lin TH (1999) Association between oxidative stress and changes of trace elements in patients with breast cancer. Clin Biochem 32: $131-136$

Kallistratos G, Evangelou A, Seferiadis K, Vezyraki P, Barboutis K (1985) Selenium and haemodialysis: serum selenium levels in healthy persons, non cancer and cancer patients with chronic renal failure. Nephron 41: 217-222

Kallistratos G, Fasske E, Karkabounas S, Charalabopoulos K (1989) Prolongation of the survival time of tumor bearing wistar rats through a simultaneous oral administration of vitamins $\mathrm{C}+\mathrm{E}$ and selenium with glutathione. Prog Clin Biol Res 259: 377-389

Kuo HW, Chen SF, Wu CC, Chen DR, Lee JH (2002) Serum and tissue trace elements in patients with breast cancer in Taiwan. Biol Trace Element Res 89: $1-11$

Lianidou ES, Melegos DN, Diamandis EP (1997) BRCA1 tumor suppressor gene product shares immunoreactive epitopes with protein present in seminal plasma. Clin Biochem 30: $425-432$

Lopez-Saez JB, Senra -Varela A, Pousa-Estevez L (2003) Selenium in breast cancer. Oncology 64: 227-231

Mannisto S, Alfthan G, Virtanen M, Kataja V, Uusitupa M, Pietinen P (2000) Toenail selenium and breast cancer-a case-control study in Finland. Eur J Clin Nutr 54: 98-103

Medina D, Thompson H, Ganther H, Ip C (2001) Se - methylselenocysteine: a new compound for chemoprevention of breast cancer. Nutr Cancer 40: $12-17$

Rayman MP (2000) The importance of selenium to human health. Lancet 356: $233-241$

Rayman MP (2005) Selenium in cancer prevention: a review of the evidence and mechanism of action. Proc Nutr Soc 64: 527-542

Sharma K, Mittal DK, Kesarwani RC, Kamboj VP, Chowdher Y (1994) Diagnostic and prognostic significance of serum and tissue trace elements in breast malignancy. Indian J Med Sci 48: $227-232$

Simopoulos AP (2004) The traditional diet of Greece and cancer. Eur J Cancer Prev 13: 219-230

Thorling EB, Overvad K, Geboers J (1986) Selenium status in Europe human data. A multicenter study. Ann Clin Res 18: 3-7

Wolff MS, Weston A (1997) Breast cancer risk and environmental exposures. Environ Health Persp 105(Suppl 4): 891-896 